\title{
How Self-Efficacy Drives Job Performance: The Role of Job Anxiety and Intrinsic Motivation
}

\author{
Nurlaely Razak \\ Sekolah Tinggi Ilmu Ekonomi Makassar (STIEM) Bongaya \\ Email Address: \\ nurlaely0705@gmail.com
}

\begin{abstract}
This study seeks to investigate self-efficacy on job performance through the role of work anxiety and intrinsic motivation. The research sample consisted of 83 employees and ten leaders on the STIEM Bongaya campus, and data analysis used Warp PLS 7.0. This study does not support the hypothesis that the better the self-efficacy, the higher the job performance. So, as a practical implication, self-efficacy is not the main determining factor in determining the value of job performance in tertiary institutions. Interestingly, selfefficacy has a positive and significant effect on work anxiety, and subsequently, job performance is getting better. It was found that the better the self-efficacy, the better the intrinsic motivation, and the better job performance. Hence, the role of work anxiety and intrinsic motivation as a complete mediation variable. The higher the self-efficacy, the higher the anxiety and the higher the job performance, but the impact is not significant or significant. Furthermore, the better the self-efficacy, the higher the intrinsic motivation and higher job performance, but the impact is not significant.
\end{abstract}

Keywords: self-efficacy, anxiety, intrinsic motivation, performance.

\begin{abstract}
Abstrak: Penelitian ini berusaha menginvestigasi efikasi diri terhadap kinerja pekerjaan melalui peran kecemasan bekerja dan motivasi intrinsic. Sampel penelitian yakni karyawan 83 orang dan pimpinan 10 orang pada kampus STIEM Bongaya dan analisis data menggunakan WarpPLS 7.0. Ternyata, Penelitian ini tidak mendukung hipotesis bahwa semakin baik efikasi diri semakin tinggi kinerja pekerjaan. Artinya, efikasi diri bukan faktor penentu utama dalam menetukan nilai kinerja pekerjaan pada intitusi perguruan tinggi. Menariknya, efikasi diri berbengaruh positif dan signifikan terhadap kecemasan bekerja dan selanjutnya kinerja pekerjaan semakin baik. Ditemukan bahwa semakin baik efikasi diri semakin baik motivasi intrinsik dan semakin baik kinerja pekerjaan. Kemudian, peran kecemasan bekerja dan motivasi intrinsic sebagai variabel mediasi sempurna (complete mediation). Sebab, semakin baik efikasi diri semakin tinggi kecemasan dan kinerja pekerjaan semakin tinggi namun dampaknya tidak bermakna atau signifikan. Selanjutnya, semakin baik efikasi diri semakin tinggi motivasi intrinsik dan kinerja pekerjaan semakin tinggi namun dampaknya tidak bermakna atau signifikan.
\end{abstract}

Kata kunci: Efikasi diri, kecemasan, motivasi intrinsic, kinerja. 


\section{INTRODUCTION}

Many practitioners and academics are trapped by the work performance measurement model, which is based solely on the work performance produced under standards. The measure of job performance is more than that, and it seems that there has not been a comparison of beneficial values for individuals and institutions for the resulting achievements. It is necessary to work awareness and produce results above the standard average, on time, and with quality in having valuable achievements. Of course, employees will display valuable job performance for individuals and institutions.

Work performance will be better and more valuable if there is a good and quality drive of self-efficacy because self-efficacy is a portrait of the behavior of individuals who have strong beliefs so that employees can complete their tasks according to standards, on time, of quality and value (Engku et al., 2020; Kaakeh et al., 2020). Research by Khedhaouria et al., 2015); (Lyons and Bandura, 2019) stated that the better self-efficacy, the higher the job performance. Thus, employees who have good self-efficacy are employees who have creativity. Because the better the work created, the better the selfefficacy and the stronger the job performance. (Li et al., 2020) show evidence that the relationship between self-efficacy and individual creative performance is an inverted Ushaped.

Employees who have good self-efficacy and quality can reduce work anxiety. Research by (Hur et al., 2020) reports that good self-efficacy will certainly be more creative in work to better work performance. These employees often display optimism and do not feel bored at work, and they do not display polluted work behavior (Harju et al., 2016). Such behavior can only be found in employees who have good self-efficacy. Tend to show like looking and love work (Zalewska, 2011) and not easily stressed out at work (Jiang et al., 2019). Therefore, self-efficacy is related to anxiety at work and has an impact on job performance. Because the better self-efficacy, the lower the anxiety at work and the higher the performance (De Clercq et al., 2018).

Self-efficacy can generate intrinsic motivation at work. Of course, employees who have a sense of competence and deliver valuable performance can certainly be employees who have good intrinsic motivation content that was born with a strong belief that they can get the job done well to perform well. Research, (Heyder et al., 2020) stated that belief in working could strengthen social bonds. Also, (Feng et al., 2018) stated that self-efficacy has a significant relationship with intrinsic motivation through the offering of values in the form of self-presentation, social ties, and fun so that work performance is good and quality. Also, firm (Hayati and Caniago, 2012); (Kimura et al., 2019) stated that the better the intrinsic motivation, the better the job performance.

This study aims to find answers to the relationship between self-efficacy and job performance on the STIEM Bongaya campus, which is mediated by the role of anxiety in work and intrinsic motivation. The STIEM Bongaya campus is chaired by a secondgeneration foundation that has put a cool working atmosphere and motivates management, including employees, to produce good and quality performance so that it is interesting to conduct research.

This article is organized into several sections: a theoretical study, methodology; research result; discussion; last conclusion. 


\section{THEORITICAL REVIEW}

Self-efficacy and job performance. Self-efficacy is a belief and self-confidence in an employee's ability to work with a conscious, intelligent, and valuable motive. Given the conservation of resources (COR) theory, employees always try to maintain their abilities based on the values of awareness in doing work intelligently and producing valuable work (Hobfoll et al., 1990). The right meaningful work awareness encourages self-efficacy. (Engku et al., 2020); (Kaakeh et al., 2020) reported that work awareness is a driver of selfefficacy in doing good and valuable work. It is because someone who has high work awareness has high morale and is $\mathrm{n}$ accordance with the institution's needs (Sugahara et al., 2010).

The quality of self-efficacy by employees can be seen from their creative role because the better the work creativity, the better the self-efficacy, and the stronger the job performance. Research by (Li et al., 2020) shows an inverse U-shaped relationship between self-efficacy and individual creative performance. Even though the low self-efficacy is low, the creativity of the performance is getting higher. Furthermore, a certain point decreases in creativity along with increasing self-efficacy. There is a tendency if there is no organizational or leadership support; self-efficacy also decreases, resulting in a decrease in work creativity value. Thus, a decrease in the self-efficacy value will have an impact on the decrease in job performance. It is evidenced by research by (Afzal et al., 2019) that perceived supervisor support affects self-efficacy and results in a decrease in work creativity intentions. In other words, the decline in performance is caused by a lack of professional employees in doing work so that they cannot encourage job performance. However, some think that professionalism is not a determining factor in encouraging employees' job performance (Bennett, 2011). Therefore, (Khedhaouria et al., 2015); (Lyons and Bandura, 2019) stated that the better self-efficacy, the higher the job performance. So the research hypothesis is:

\section{H1: Self-efficacy has a positive effect on job performance.}

Self-efficacy and anxiety at work. Psychologically, when employees are seized by feelings of tension, nervousness, restlessness, worry, and fear, they will show emotions of fear or anxiety. This psychological condition is known as work anxiety. Employees who have good self-efficacy will be able to control work anxiety. The COR theory's perspective is that individuals who can protect themselves from anxiety will display a strong personality, especially in the face of work (Hobfoll and Lilly, 1993; 2001). A way to reduce anxiety tension is through work assistance. (Kachaturoff et al., 2020) explained that peer mentoring could reduce stress and short-term anxiety levels. Besides, employees must be encouraged to do creativity that benefits the institution. (Hur et al., 2020) stated that good self-efficacy would certainly be more creative in work to have better work performance. Also, reliable employees are looking for job challenges to avoid work boredom, and work pollution can certainly decrease (Harju et al., 2016). The study of (De Clercq et al., 2018) illustrates that when he does work hastily, it means he is experiencing work anxiety, and his self-efficacy is not good.

Furthermore, (Deer et al., 2018) stated that the higher the self-efficacy, the lower the anxiety level if the intention or desire to seek work is high. Furthermore, it will increase job 
satisfaction (Zalewska, 2011). In addition to getting job satisfaction, this behavior can also reduce stress and anxiety in workers. Research by (Jiang et al., 2019) states that collective environmental factors are significantly associated with workers' stress and anxiety. Therefore, the research hypothesis is:

H2: Self-efficacy has a negative effect on work anxiety.

Anxiety in work and job performance. Job performance can be interpreted as work performance according to standards or above standards and is meaningful to individuals and institutions. Employees who have a low level of work anxiety will produce good and quality job performance. The lower the anxiety, the higher the job performance. Recognizing the work environment helps prevent work anxiety from performing well and get job satisfaction (Zalewska, 2011). Employees who have a quality personality will certainly reduce anxiety levels so that their performance is good (Kaakeh et al., 2020). Then, (De Clercq et al., 2020) stated that employees who are not grateful for what is given by the organization can reduce performance because they are always haunted by higher anxiety at work. Therefore, the better self-efficacy, the lower the work's anxiety and the higher the performance (De Clercq et al., 2018). Thus, the next pituitary:

H3: Anxiety at work has a negative effect (harm) on job performance.

H4: Self-efficacy has a positive effect on job performance through work anxiety.

Self-efficacy and intrinsic motivation. Employees who feel competent and perform well and meaningfully are employees who have good intrinsic motivation. He always makes changes, from not performing well to performing employees. Because when he can do a good job, he has a superior job, and he believes that the job is more meaningful for him than the institution. (Heyder et al., 2020) stated that realizing the success of their abilities will make them work a lot because there are social ties. Furthermore, (Feng et al., 2018) stated that self-efficacy was significantly related to intrinsic motivation through the offering of values in the form of self-presentation, social ties, and fun. Awareness produces quality selfefficacy and strengthens intrinsic motivation. (Chaurasia et al., 2019) suggests a positive relationship between awareness and intrinsic motivation. The characteristics of the work ethic are employees who have intrinsic motivation and strive for job satisfaction. (Hayati and Caniago, 2012) explain that employees with a work ethic will strengthen intrigue motivation to get job satisfaction. Therefore, self-efficacy portraits are employees who have high hopes that they will contribute to the institution. Then the research hypothesis is:

\section{H5: Self-efficacy has a positive effect on intrinsic motivation.}

Intrinsic motivation and job performance. It is believed that intrinsic motivation is related to job performance. (Hayati and Caniago, 2012); (Kimura et al., 2019) stated that the better the intrinsic motivation, the better the job performance. Employees who are motivated to work are employees who believe that work is more meaningful to themselves, so job performance is high. (Heyder et al., 2020) stated that the higher the belief, the higher the intrinsic motivation and the better the performance. Of course, these employees like new 
job challenges. (Jabagi et al., 2019) stated that employees who like challenges tend to build social relationships with their peers to make their performance good. Therefore, they always display work behavior that is not just symbolic or ceremonial. Employees display real and valuable work as a form of quality self-efficacy. It can be ascertained that he has a high intrinsic motivation to produce good and quality job performance. The research of (Çetin and ASkun, 2018) states that the better self-efficacy, the higher the intrinsic motivation and the better the performance. Therefore, the proposed hypothesis is:

H6: Intrinsic motivation has a positive effect on job performance.

H7: Self-efficacy has a positive effect on positive job performance mediated by intrinsic motivation.

\section{METHODS}

Data and sample. For accurate and reliable information about self-efficacy, work anxiety, and intrinsic motivation, this study distributed questionnaires to employees as respondents as many as 83 people. The job performance information was given the opportunity by Campus Leaders, including the Chair and Secretary of the Study Program, as many as ten people. Respondents were allowed to respond for two weeks. The questionnaires collected from employee respondents were $80(86.02 \%)$, and the leaders were seven respondents $(7.58 \%)$ so that the total questionnaires collected were 87 (93.60\%). All question items contained in the questionnaire have obtained complete answers according to the required information. Demographics of respondents show that 55 percent of the employees are male, and 45 percent of the female employees are at the STIEM Bongaya Campus. The average age of employees is between 20 and 35 years at 55 percent and between 36 and 55 years old at 40 percent. This campus was founded in the 1970 s, so the age of this campus is quite old, so that some employees whose work period is 1-2 years is 20 percent, 3-5 years is 18 percent and a work period of $>5$ years is 62 percent. Meanwhile, the education level of employees is dominated by undergraduates at 97 percent.

\section{RESULT}

Model goodness. The model is declared good if the $\mathrm{p}$-value $<0.05$ on each indicator, namely the Average path coefficient (APC), Average R-squared (ARS), and Average adjusted Rsquared (AARS) (see Table 1). The APC value of 0.461 is close to $50 \%$, so it can be stated that the independent variable can respond to the dependent variable. Furthermore, the ARS is 0.570 , which indicates that the average determinant correlation is above $50 \%$, so that between variables is stated to correlate. Then, the AARS value is 0.561 , which means that several independent variables' correlation is above $50 \%$. Therefore, the model can be good because it is above 50\% and has a p-value of $\mathrm{P}<0.001$ (Sumail and Abdullah, 2019). 
Table 1. Model Goodness

\begin{tabular}{lccc} 
& \multicolumn{3}{c}{ Model Goodness indicator } \\
\cline { 2 - 4 } & APC & ARS & AARS \\
\cline { 2 - 4 } $\begin{array}{l}\text { Result of the } \\
\text { analysis } \\
\text { Conclusion }\end{array}$ & Good & $0.570,(\mathrm{p}=0.001)^{* * *}$ & $0.561,(\mathrm{p}=0.001)^{* *}$ \\
Note: Criteria for Fit $\mathrm{p}$ value $<0.05$ or $* *$ & Good & Good \\
\hline
\end{tabular}

Measurement. Before the questionnaire is distributed to respondents, it begins with measuring the item is valid or reliable. The validity criterion is if the factor load is $>0.30$ or $\mathrm{p}<0.001$, and the reliability criterion is if the alpha coefficient is above 0.70 (Solimun et al., 2017). Each question item uses a five-point Likert scale ranging from 1 (strongly disagree) to 5 (strongly agree).

Self-efficacy at work. Self-efficacy is a belief or confidence by employees regarding their ability to carry out a task, which is implemented in smart and valuable actions. The selfefficacy measurement used six items (see Table 2). The six self-efficacy measurement items fulfilled the validity criteria because the factor load was $>0.30$ or $p<0.001$. Furthermore, the test results for the alpha coefficient are above the value of 0.773 , so that all items are declared reliable. A high item-value reflecting increased self-efficacy at work was "when I have a problem at work, I can usually find some solutions" of 0.768 .

Table 2. Constructs and Measurement Items Self-Efficacy

\begin{tabular}{lcc}
\hline \multicolumn{1}{c}{ Items } & $\begin{array}{c}\text { Factor } \\
\text { loading }\end{array}$ & p-Value \\
\hline When I have problems at work, I can usually find some meaningful & 0.768 & $<0.001$ \\
solutions. & 0.686 & $<0.001$ \\
I feel confident at work because I have working creativity. & 0.559 & $<0.001$ \\
I feel empowered to organize and carry out a smart and valuable action that \\
my workplace needs.
\end{tabular}

Work anxiety. Anxiety is a psychological condition reflected in the emotions of employees who tend to be haunted by feelings of tension, nervousness, restlessness, worry, fear, so that it has an impact on decreased self-confidence in doing a job. 
Table 3. Constructs and Measurement Items of Anxiety in Work

\begin{tabular}{lcc}
\hline \multicolumn{1}{c}{ Items } & $\begin{array}{c}\text { Factor } \\
\text { loading }\end{array}$ & p-Value \\
\hline I feel uneasy because of the work I do not completed according to schedule. & 0.524 & $<0.001$ \\
Sometimes I feel restless when I think about work. & 0.550 & $<0.001$ \\
I feel guilty when I take time off from my job. & 0.588 & $<0.001$ \\
I love work so I can reduce anxiety at work. & 0.815 & $<0.001$ \\
Before I do a job, I recognize the field of work so I can be confident at work. & 0.808 & $<0.001$ \\
I try to be grateful for what the organization provides so that I am not & 0.394 & $<0.001$ \\
haunted by anxiety. & & \\
\hline
\end{tabular}

In obtaining accurate information, work anxiety is measured by six items (see Table 3 ) with a Likert scale pattern. The six items measuring anxiety in work fulfilled the validity criteria because the factor load was $>0.30$ or $\mathrm{p}<0.001$. Furthermore, the alpha coefficient test results are above the value of 0.797 so that all indicators are declared reliable. Questions such as "I like to find work so I can reduce workplace anxiety" of 0.815 are high item scores reflecting job anxiety.

Intrinsic motivation. Intrinsic motivation is the feeling of employees who have been challenged or competent in doing meaningful or meaningful work, measuring the level of intrinsic motivation by employees through six-question items based on a Likert scale. The results of the validity measurement were due to the factor load $>0.30$ or $p<0.001$. Moreover, the alpha coefficient's test results are above the value of 0.774 so that all items of the intrinsic motivation variable are declared reliable. The item of the question "I am motivated to work because I believe the job is more meaningful to myself" is the item that has the highest weight in reflecting the intrinsic motivation of employees of 0.808 (see Table 4).

Table 4. Constructs and Measurement Items of Intrinsic Motivation

\begin{tabular}{lcc}
\hline \multicolumn{1}{c}{ Items } & $\begin{array}{c}\text { Factor } \\
\text { loading }\end{array}$ & p-Value \\
\hline I enjoy working according to my competence. & 0.336 & $<0.001$ \\
I do this work because I hope that I can provide benefits for tomorrow. & 0.584 & $<0.001$ \\
I feel there are challenges at work and I try to produce valuable work. & 0.653 & $<0.001$ \\
I am motivated to work because I believe that work is more meaningful to & 0.797 & $<0.001$ \\
me. & 0.646 & $<0.001$ \\
I work based on awareness so that I produce meaningful work, not symbolic & & \\
or ceremonial. & 0.621 & $<0.001$ \\
\hline
\end{tabular}

Job performance. Job performance, such as employees' work performance under the standards or above the organization's standards. Measurement of job performance by employees is done by providing six-question items and using a Likert scale. 
Table 5. Constructs and Measurement Items of Job Performance

\begin{tabular}{lcc}
\hline \multicolumn{1}{c}{ Items } & $\begin{array}{c}\text { Factor } \\
\text { loading }\end{array}$ & p-Value \\
\hline $\begin{array}{l}\text { Employees feel they have a high personal responsibility so that they produce } \\
\text { quality and valuable performance. }\end{array}$ & 0.715 & $<0.001$ \\
$\begin{array}{l}\text { Employees make use of existing resources so that they produce performance } \\
\text { according to standards. }\end{array}$ & 0.550 & $<0.001$ \\
$\begin{array}{l}\text { Employees take advantage of concrete feedback in all work activities so that } \\
\text { they produce effective and sustainable performance. }\end{array}$ & 0.707 & $<0.001$ \\
$\begin{array}{l}\text { Employees are always looking for opportunities to put work plans into } \\
\text { action on time. }\end{array}$ & 0.613 & $<0.001$ \\
$\begin{array}{l}\text { Employees feel they have a high commitment and responsibility for the } \\
\text { tasks assigned to them. }\end{array}$ & 0.554 & $<0.001$ \\
$\begin{array}{l}\text { Employees have the courage to take and bear the risks associated with } \\
\text { institutional development. }\end{array}$ & 0.417 & $<0.001$ \\
\hline
\end{tabular}

Of the six items, it can be stated that they meet the validity criteria because the factor load is $>0.30$ or $p<0.001$, and it can also be stated that they meet the reliability criteria because the alpha coefficient is above the value of 0.853 . The item of the question "Employees feel they have a high personal responsibility so that I produce quality and valuable performance" is the item that has the highest weight in characterizing job performance by employees of 0.715 (see Table 5).

Table 6. Result of path coefficients

\begin{tabular}{|c|c|c|c|c|c|c|}
\hline \multicolumn{2}{|c|}{ Independent variable } & \multicolumn{2}{|c|}{ Dependent variable } & Coefficient & SE & p-value \\
\hline \multicolumn{2}{|c|}{ Self-efficacy (X) } & \multicolumn{2}{|c|}{ Job performance (Y3) } & 0.039 & 0.11 & 0.362 \\
\hline \multicolumn{2}{|c|}{ Self-Efficacy (X) } & \multicolumn{2}{|c|}{$\begin{array}{l}\text { Anxiety that relaxes } \\
\text { work (Y1) }\end{array}$} & $0.809 * * *$ & 0.09 & 0.001 \\
\hline \multicolumn{2}{|c|}{ Self-Efficacy (X) } & \multicolumn{2}{|c|}{$\begin{array}{l}\text { Intrinsic motivation } \\
(\mathrm{Y} 2)\end{array}$} & $0.720 * * *$ & 0.09 & 0.001 \\
\hline \multirow{2}{*}{\multicolumn{2}{|c|}{$\begin{array}{l}\text { Anxiety that relaxes work } \\
\text { (Y1) } \\
\text { Intrinsic Motivation (Y2) }\end{array}$}} & \multicolumn{2}{|c|}{ Job performance (Y3) } & $0.309 * * *$ & 0.10 & 0.001 \\
\hline & & \multicolumn{2}{|c|}{ Job performance (Y3) } & $0.415^{* * *}$ & 0.10 & 0.001 \\
\hline $\begin{array}{l}\text { Independent } \\
\text { variable }\end{array}$ & \multicolumn{2}{|c|}{$\begin{array}{l}\text { Mediating } \\
\text { variables }\end{array}$} & $\begin{array}{c}\text { Dependent } \\
\text { variable }\end{array}$ & Coefficient & SE & p-value \\
\hline $\begin{array}{l}\text { Self-Efficacy } \\
(\mathrm{X})\end{array}$ & \multicolumn{2}{|c|}{$\begin{array}{l}\text { Anxiety that } \\
\text { relaxes work } \\
\text { (Y1) }\end{array}$} & $\begin{array}{l}\text { Job } \\
\text { performance } \\
\text { (Y3) }\end{array}$ & $0.548 * * *$ & 0.09 & 0.001 \\
\hline $\begin{array}{l}\text { Self-Efficacy } \\
(\mathrm{X})\end{array}$ & \multicolumn{2}{|c|}{$\begin{array}{l}\text { Intrinsic } \\
\text { motivation (Y2) }\end{array}$} & $\begin{array}{l}\text { Job } \\
\text { performance } \\
\text { (Y3) }\end{array}$ & $0.093 * * *$ & 0.09 & 0.001 \\
\hline \multicolumn{7}{|c|}{$\begin{array}{l}\text { Information: } * * *=\text { highly significant at } \alpha=0.01 * *=\text { significant at } \alpha=0.05 ; *=\text { weakly significan } \\
\text { at } \alpha=0.10 .\end{array}$} \\
\hline
\end{tabular}




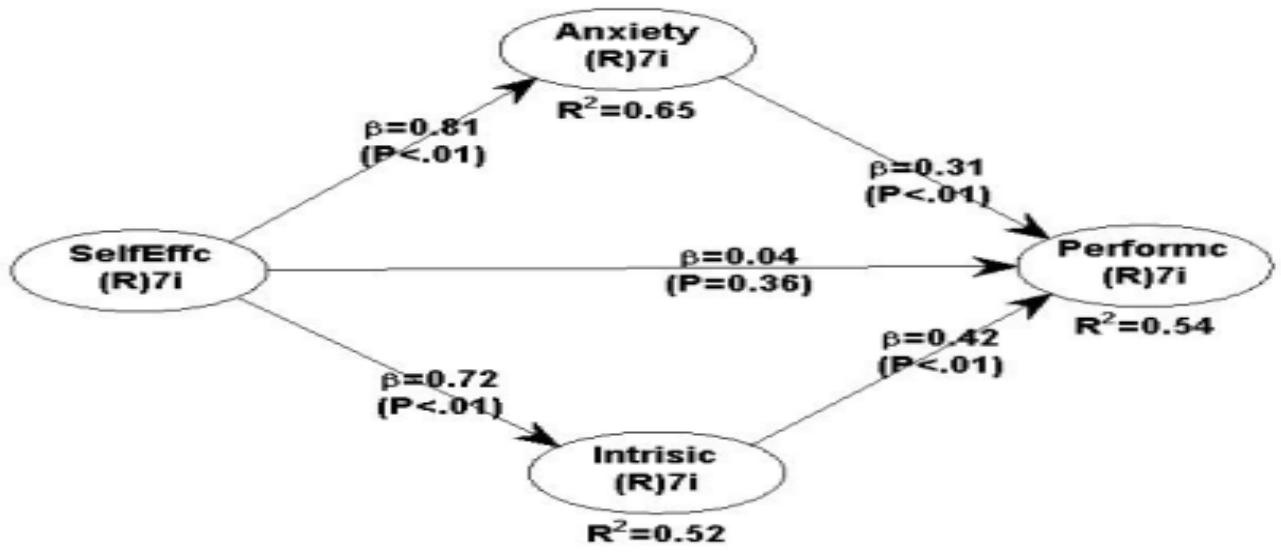

Figure 1. Model Research Results

\section{DISCUSSION}

This study found that self-efficacy was positively related but not significant to job performance, or this study did not support the hypothesis that the better self-efficacy, the better job performance. The ability and confidence to do work do not give meaning or do not mean anything to job performance. It is due to employees' tendency to lose the meaning of their abilities when doing work, or it may be that employees' actions tend to be less intelligent so that the value of job performance can dim. In other words, employees who are less professional in doing work are not meaningful in encouraging job performance. Research by (Bennett, 2011) reports that professionalism is not a determining factor in employees' encouraging job performance.

It is not an exaggeration to state that the indication of awareness and morale is still low, so that it has an impact on decreasing the meaning of the relationship between selfefficacy and job performance. Work awareness can be interpreted as a psychological portrait of the ability to understand or recognize one's feelings to make smart and meaningful actions. Therefore, the meaning of consciousness is lost or dim, resulting in a decrease in the meaning of self-efficacy. (Engku Kamarudin et al., 2020); (Kaakeh et al., 2020) reported that work awareness is a driver of self-efficacy in doing good and valuable work. Someone who has a high work awareness has high morale as well. His enthusiasm is for employees to do work $\mathrm{n}$ accordance with the institution's needs (Sugahara et al., 2010).

Other indications were also found, namely that the employee's work creativity seemed to decrease. Decreasing work creativity will result in a loss of meaning in the role of self-efficacy on job performance. The better the work created, the better the self-efficacy, and the stronger the job performance. Is proven empirically by ( $\mathrm{Li}$ et al., 2020) an inverse U-shaped relationship between self-efficacy and individual creative performance. That is, the lower the self-efficacy, the higher the creativity performance. Furthermore, at a certain point, creativity decreases along with increasing self-efficacy. When there is no organizational support or leadership, self-efficacy also decreases, resulting in a decrease in the value of work creativity intentions. When the self-efficacy value decreases, it will 
certainly impact decreasing the meaning of job performance. Research by (Afzal et al., 2019) provides evidence that perceived supervisor support affects self-efficacy and decreases work creativity intentions.

A practical implication related to self-efficacy with job performance is encouraging employees to do smart work to drive the value of job performance. Then, instill the values of awareness and morale to strengthen self-efficacy and encourage job performance. It is not enough to do work that is motivated by smart work and work awareness, but employees' creativity is of particular concern to institutions if self-efficacy and work performance are more valuable and sustainable.

In avoiding a decrease in the meaning of self-efficacy and job performance, management needs to maintain a position on employee motivation to work, such as involvement in institutional development strategies. Because employees who feel confident in their high involvement in work (Luthans and Peterson, 2002). Their involvement as a portrait that they have the competence and experience they have can strengthen employee self-efficacy.

Furthermore, the position that must be maintained is doing work ethically, so that job performance has meaning. Working with ethical values is a strong portrait of an employee's self-efficacy. Research by (Sukserm and Takahashi, 2012) states that employee self-efficacy increases and is meaningful if they have self-confidence and do work ethically. That is, the stronger the ethics, the more confident employees are, and the better selfefficacy. Finally, the position that needs to be maintained is employees' ability to find solutions when facing work problems. This behavior reflects the skills to find solutions to produce good and valuable job performance. Research by (Gashi Tresi and Mihelič, 2018) reports that employees who have job crafting will strengthen self-efficacy and encourage performance.

This study does not support the hypothesis proposed by (Khedhaouria et al., 2015); (Lyons and Bandura, 2019) that the better self-efficacy, the higher the job performance. Therefore, as a practical implication, self-efficacy is not the main determining factor in determining the value of job performance in tertiary institutions. It may be that self-efficacy will be meaningful to employees' work performance on other objects or outside the STIEM Bongaya Campus object.

This study does not support the hypothesis that the better the self-efficacy, the lower the work's anxiety. Empirical evidence shows that the better the self-efficacy, the higher the anxiety at work. The self-efficacy displayed by STIEM Bongaya employees has not been able to reduce anxiety at work. Even though self-efficacy seems high, on the other hand, some employees have not felt the benefit of the mentoring role of coworkers, which still seems low. It is addressed to employees whose work period is 1-2 years as much as 20 percent tend to be inexperienced in work so that their anxiety tin work is high. (Kachaturoff et al., 2020) stated that peer mentoring reduces stress and short-term anxiety level situations, especially for inexperienced employees.

Another factor as a cause of anxiety at work is high because employee involvement in creativity is still low. Work creativity is the ability of employees to create work results that others have not found. Employees who have good self-efficacy will certainly be more creative at work to better their work performance (Hur et al., 2020). It seems that employees do not have a sense of work challenges, and the work they do is still seemingly routine as a result of boredom at work, so that anxiety at work is high. (Harju et al., 2016) reported that 
employees who like to seek job challenges would avoid work boredom, and work pollution can decrease.

STIEM Bongaya employees who tend to do work in a hurry can potentially cause anxiety at work. Employees who do work in a hurry will certainly reduce enjoyment at work so that the potential for work anxiety will arise. Conversely, employees who enjoy their work are less likely to display a hasty attitude and produce higher performance (De Clercq et al., 2018). Supposedly, employees have a high sense of guilt when they take time off work, so work anxiety tends to be below. Nevertheless, what was found in STIEM Bongaya employees was a common sense of guilt when he took time off so that work anxiety was high.

To maintain employees is their job-seeking behavior, that the job is important to them apart from the institution so that the potential for anxiety in the workplace can be reduced. This behavior arises because of good self-efficacy. Research (Deer et al., 2018) stated that the higher the self-efficacy, the lower the level of anxiety if the intention or desire to seek work is high and the institution always provides career opportunities for employees. Reality shows that before he does work, he tries to identify work and the environment to get satisfaction at work because the higher the job satisfaction, the lower the anxiety (Zalewska, 2011). In addition to getting job satisfaction, this behavior can also reduce stress and anxiety in workers. Research by (Jiang et al., 2019) states that collective environmental factors are significantly associated with workers' stress and anxiety.

Anxiety in work has implications for job performance by employees. Nevertheless, this study does not support the hypothesis that the lower the work's anxiety, the higher the job performance. Empirical evidence shows that the higher the anxiety at work, the higher the job performance. Although anxiety in work is high, employees have awareness and love for work because work is important to them apart from the institution. What is unforgettable is that before commencing workers, they begin by recognizing the work environment to get job satisfaction (Zalewska, 2011) and have an impact on improving job performance. Employees who have high awareness are employees who love to work. Automatic selfefficacy is strong, and subsequently, the job performance is getting better. Because he loves his job, he feels to have a high personal responsibility to produce quality and valuable performance. (Kaakeh et al., 2020) reported that awareness positively affects self-efficacy and subsequently affects the individual's performance and image getting better.

Furthermore, employees who have the awareness and love of work will not show an attitude of betrayal and avoid the meanings of organizational goals. (De Clercq et al., 2020) stated that betrayal and not being grateful for what is given by the organization can reduce performance because it is always haunted by higher anxiety in daily work. Thus, anxiety is not a barrier factor in doing work with the assumption of good self-efficacy. Ideally, selfefficacy increases, the level of anxiety at work is low, so performance increases (De Clercq et al., 2018).

This study's results are in line with (De Clercq et al., 2018) that increasing employee self-efficacy can improve job performance if they experience less anxiety while doing daily work tasks. Therefore the mediating role of work-related anxiety is very prominent because employees believe that they are working with awareness followed by a sense so that their behavior is civilized. Thus, as a practical implication, the management of the STIEM Bongaya Campus must strengthen self-efficacy, reduce the potential for work anxiety, and encourage job performance. (Taylor, 2020) offers three types of interventions to deal with 
various types of work-related anxiety: (1) conducting programs that motivate people to overcome anxiety and take action to reduce the effects of work climate change, (2) conduct anxiety therapy to avoid work stress, and (3) undertake resilience-building programs at the individual and community level to help people better cope with the challenges of the future.

Self-efficacy has a role in intrinsic motivation. Empirical evidence supports the hypothesis that the better the self-efficacy, the higher the self-motivation. Employee behavior characterized by a sense of competence and a sense of urgency in doing work is an employee who has good and valuable intrinsic motivation. At least, employees can make changes, from not performing well to performing employees. Employees who are motivated to work are employees who believe that work is more meaningful to them. (Heyder et al., 2020) stated that the belief in realizing one's abilities and obstacles is important in creating an atmosphere of work involvement. Employees who always feel that there are challenges at work can be sure to get social bonds and enjoyment of work. He always presents the best as a form of self-efficacy. In line with (Feng et al., 2018), self-efficacy is significantly related to intrinsic motivation through the offering of values in the form of self-presentation, social ties, and fun.

High self-efficacy is believed to be due to the inherent value of working awareness so that a sense of competitiveness tends to be high. It works based on consciousness so that it produces meaningless work, not symbolic or ceremonial. Research by (Chaurasia et al., 2019) suggests a positive relationship between awareness and intrinsic motivation. It means that work awareness creates a sense of competence in producing works of value, not only symbolic or ceremonial works. Of course, the employee will present the best so that he will get job satisfaction. Only those with a work ethic will have high intrinsic motivation who will get job satisfaction. (Hayati and Caniago, 2012) explain that employees with a work ethic will strengthen intrigue motivation to get job satisfaction.

What needs to be instilled in employees is to instill hope that the job can benefit the next day. Unfulfilled expectations increase work-related boredom, which and affects intrinsic motivation (Gkorezis and Kastritsi, 2010). Therefore, doing work according to competence will be more enjoyable and get job satisfaction.

Work motivation can drive job performance. Job performance is the work performance produced by employees who have value. This study supports the hypothesis that the higher the intrinsic motivation, the higher the job performance. In line with the research of (Biology and Caniago, 2012), (Kimura et al., 2019) stated that intrinsic motivation is increasingly having a positive and significant effect on job performance. Is because an employee who is motivated to work is that he believes that work is more meaningful to himself, so that job performance is high. This argument can be strengthened by (Heyder et al., 2020) that the higher the belief, the higher the intrinsic motivation, and the better the performance.

The motive of employees who like challenges will get social space so that they are happy at work. (Jabagi et al., 2019) provide evidence that being happy with challenges will strengthen social relationships with colleagues so that performance is good. Therefore, they will display work behavior that is not just symbolic or ceremonial. Only employees who have intrinsic motivation can present the best with the hope of good job performance often held into a high sense of personal responsibility so that they produce quality and valuable performance. However, employees often take advantage of concrete feedback in all work activities, looking for opportunities to realize work plans on time. 
The performance will be more meaningful if we dare to take and bear the risks associated with institutional development to produce effective and sustainable performance. So this research supports the hypothesis that the better the self-efficacy, the higher the intrinsic motivation and the better job performance. It is in line with (Çetin and ASkun's, 2018), showing that job self-efficacy and intrinsic motivation significantly affect performance, and intrinsic motivation serves as a partial mediator in this relationship. However, this study resulted in the role of intrinsic motivation as a complete mediation variable.

As a practical implication, what must be played by employees is to make changes or turn the direction from underperforming to underperforming. Therefore, awareness of work will strengthen intrinsic motivation in offering the best, so that job performance is good.

\section{CONCLUSION}

This study does not support the hypothesis that the better the self-efficacy, the higher the job performance. Thus, as a practical implication, self-efficacy is not the main determining factor in determining the value of job performance in tertiary institutions. Furthermore, it also does not support the hypothesis that the better the self-efficacy, the lower the work's anxiety. Empirical evidence shows that the better the self-efficacy, the higher the anxiety at work. The self-efficacy displayed by some STIEM Bongaya employees has not been able to reduce anxiety at work, especially for employees whose work periods are relatively young or inexperienced. Some employees have not felt the benefit of their coworkers' mentoring role, which seems low, so anxiety at work is high.

Furthermore, the factor of employee involvement in creativity is still low and still seems routine. As a result, boredom at work occurs, so that anxiety at work is high. Interestingly, job anxiety is high, but job performance is high too. It was found that some employees have work awareness and love to work so that their performance increases. It is mostly found in employees who have high involvement and experience.

As a practical implication, the management of the STIEM Bongaya Campus must strengthen self-efficacy, reduce the potential for work anxiety, and encourage job performance. The next practical implication is that employees have to make changes or turn around from not performing to underperforming. Therefore, awareness of work will strengthen intrinsic motivation in offering the best, so that job performance is good.

This study supports the hypothesis that the better the self-efficacy, the higher the intrinsic motivation and the better job performance. Therefore, the role of work anxiety and intrinsic motivation can be expressed as a complete mediation variable.

Because there is only one research object, it seems that information is limited, so that future research needs to expand the object of research, for example, several campuses in the Makassar area. 


\section{REFERENCES}

Afzal, S., Arshad, M., Saleem, S., and Farooq, O. (2019). The impact of perceived supervisor support on employees' turnover intention and task performance: Mediation of self-efficacy. Journal of Management Development, 38(5), 369-382.

Bennett, R. (2011). Brand managers mindful self-management of their professional experience: Consequences for pay, self-efficacy and job performance. Journal of Brand Management, 18(8), 545-569.

Çetin, F., and ASkun, D. (2018). The effect of occupational self-efficacy on work performance through intrinsic work motivation. Management Research Review, 41(2), 186-201.

Chaurasia, S. S., Verma, S., and Singh, V. (2019). Exploring the intention to use M-payment in India: Role of extrinsic motivation, intrinsic motivation and perceived demonetization regulation. Transforming Government: People, Process and Policy, 13(3-4), 276-305.

De Clercq, D., Azeem, M. U., and Haq, I. U. (2020). But they promised! How psychological contracts influence the impact of felt violations on job-related anxiety and performance. Personnel Review.

De Clercq, D., Haq, I. U., and Azeem, M. U. (2018). Self-efficacy to spur job performance: Roles of job-related anxiety and perceived workplace incivility. Management Decision, 56(4), 891-907.

Deer, L. B. K., Gohn, K., and Kanaya, T. (2018). Anxiety and self-efficacy as sequential mediators in US college students' career preparation. Education and Training, 60(2), 185-197.

Engku Kamarudin, E. M., Wan Sulaiman, W. S., Sarnon, N. H., and Amin, a. S. (2020). Data on self-awareness, self-determination, and self-efficacy of opioid-dependent patients receiving methadone treatment before and after getting individual psychoeducational (i-SEAZ) intervention. Data in Brief, 30(xxx), xxx-xxx.

Feng, Y., Jonathan Ye, H., Yu, Y., Yang, C., and Cui, T. (2018). Gamification artifacts and crowdsourcing participation: Examining the mediating role of intrinsic motivations. Computers in Human Behavior, 81, 124-136.

Gashi Tresi, D., and Mihelič, K. K. (2018). The roles of self-efficacy and leader-member exchange in the relationship between job crafting and work-self facilitation: A moderated mediation model. Personnel Review, 47(7), 1362-1384.

Gkorezis, P., and Kastritsi, A. (2010). Employee expectations and intrinsic motivation: work-related boredom as a mediator. The Eletronic Library, 34(1), 1-5.

Harju, L. K., Hakanen, J. J., and Schaufeli, W. B. (2016). Can job crafting reduce job boredom and increase work engagement? A three-year cross-lagged panel study. Journal of Vocational Behavior, 95-96(xxx), 11-20.

Hayati, K., and Caniago, I. (2012). Islamic Work Ethic: The Role of Intrinsic Motivation, Job Satisfaction, Organizational Commitment and Job Performance. Procedia - Social and Behavioral Sciences, 65(ICIBSoS), 272-277.

Heyder, A., Weidinger, A. F., Cimpian, A., and Steinmayr, R. (2020). Teachers' belief that math requires innate ability predicts lower intrinsic motivation among low-achieving students. Learning and Instruction, 65(October 2018), 101220. 
Hobfoll, N. E., Freendy, J., Lane, C., and Geller, P. (1990). Conservation of Social Resources: Social Support Resources Theory. Journal of Science and Personal Relationships, 7(xxx), 465-478.

Hobfoll, S. E. (2001). The influence of culture, community, and the nested-self in the stress process: Advancing conservation of resources theory. Applied Psychology, 50(3), 337-421.

Hobfoll, S. E., and Lilly, R. S. (1993). Resource conservation as a strategy for community psychology. Journal of Community Psychology, 21(2), 128-148.

Hur, W. M., Moon, T. W., and Lee, J. H. (2020). The effect of self-efficacy on job performance through creativity: the moderating roles of customer incivility and service scripts. Asia Pacific Journal of Marketing and Logistics.

Jabagi, N., Croteau, A. M., Audebrand, L. K., and Marsan, J. (2019). Gig-workers' motivation: thinking beyond carrots and sticks. Journal of Managerial Psychology, 34(4), 192-213.

Jiang, B., Wang, H., Larsen, L., Bao, F., Li, Z., and Pryor, M. (2019). Quality of sweatshop factory outdoor environments matters for workers' stress and anxiety: A participatory smartphone-photography survey. Journal of Environmental Psychology, 65(August) 26(2) 34-46.

Kaakeh, A. K., Hassan, M. K., Van-Hemmen, S., and Hossain, I. (2020). Understanding self-efficacy and performance of salespersons in Islamic banking. Journal of Islamic Accounting and Business Research, 11(5), 973-988.

Kachaturoff, M., Caboral-Stevens, M., Gee, M., and Lan, V. M. (2020). Effects of peermentoring on stress and anxiety levels of undergraduate nursing students: An integrative review. Journal of Professional Nursing, 36(4), 223-228.

Khedhaouria, A., Gurău, C., and Torrès, O. (2015). Creativity, self-efficacy, and small-firm performance: the mediating role of entrepreneurial orientation. Small Business Economics, 44(3), 485-504.

Kimura, T., Bande, B., and Fernández-Ferrín, P. (2019). The roles of political skill and intrinsic motivation in performance prediction of adaptive selling. Industrial Marketing Management, 77(July), 198-208.

Li, C. R., Yang, Y., Lin, C. J., and Xu, Y. (2020). The curvilinear relationship between within-person creative self-efficacy and individual creative performance: the moderating role of approach/avoidance motivations. Personnel Review, $x x x(2016)$, $\mathrm{xxx}-\mathrm{xxx}$.

Luthans, F., and Peterson, S. J. (2002). Employee engagement and manager self-efficacy: implications for managerial effectiveness and development. Journal of Management Development, 21(5), 376-387.

Lyons, P., and Bandura, R. (2019). Self-efficacy: core of employee success. Development and Learning in Organizations, 33(3), 9-12.

Sugahara, S., Suzuki, K., and Boland, G. (2010). Students' major choice in accounting and its effect on their self-efficacy towards generic skills: An Australian study. Asian Review of Accounting, 18(2), 131-147.

Sukserm, T., and Takahashi, Y. (2012). Self efficacy as a mediator of the relationships between learning and ethical behavior from human resource development in corporate social responsibility activity. Asia-Pacific Journal of Business Administration, 4(1), $8-22$. 
Sumail, L. O., and Abdullah, S. (2019). Innovative Behavior And Emotional Intelligence Of Managers In Managing A Catering Business. Jurnal Manajemen, 23(2), 290.

Taylor, S. (2020). Anxiety disorders, climate change, and the challenges ahead: Introduction to the special issue. Journal of Anxiety Disorders, 76(September), 102313. h

Zalewska, A. M. (2011). Relationships between anxiety and job satisfaction - Three approaches: "Bottom-up", "top-down" and "transactional." Personality and Individual Differences, 50(7), 977-986. 